Marta WÓJCIK ${ }^{1}$

\title{
WASTE IN THE GEOPOLYMERIZATION PROCESS. PROPOSAL OF THE USE OF ASBESTOS AND FLY ASHES IN THE PRODUCTION OF GEOPOLYMER CONCRETE
}

\begin{abstract}
Due to the specific physical, chemical and mechanical properties, the worldwide production of geopolymers is increasing systematically. The high mechanical resistance and the low sensitivity to the high temperature result in the application of geopolymers in many sectors of economy, especially in civil engineering. Additionally, the low emission of carbon dioxide caused that geopolymers are often called "green" material. The wide range of the application of geopolymers requires new substances which could be used in their production. From environmental point of view, the use of waste products in the production of geopolymers is the best solution. Due to the content of silica and aluminum, asbestos dust might be successfully used in the synthesis of geopolymers. This article presents the possibility of recycling of asbestos waste and coal fly ashes in the production of geopolymer concrete. The final product of this method might be used in the construction industry without the risk for the environment. The proposed solution enables to utilize the harmful material, i.e. asbestos dust in accordance with the waste hierarchy and sustainable development.
\end{abstract}

Keywords: asbestos waste, fly ash, geopolymers, recycling, construction industry, civil engineering

\section{Introduction}

Geopolymer is an amorphous, inorganic substance which is synthesized in alkaline conditions in the temperature below $100^{\circ} \mathrm{C}$ [1]. The first-time definition of the aforementioned material was introduced by Joseph Davidovits in 1970 [2]. Geopolymers are chemically classified as an aluminosilicate in which silica ( $\mathrm{Si}$ ) and aluminium $(\mathrm{Al})$ are lined each other by means of oxygen, for example: (-Si$\mathrm{O}-\mathrm{Al}-\mathrm{O})_{\mathrm{n}}$ or $(-\mathrm{Si}-\mathrm{O}-\mathrm{Al}-\mathrm{O}-\mathrm{Si}-\mathrm{O})_{\mathrm{n}}$ (Fig. 1) [3, 4].The simplified chemical formula of geopolymers might be expressed as the following (1) [5]:

\footnotetext{
${ }^{1}$ Autor do korespondencji/corresponding author: Marta Wójcik, Rzeszow University of Technology, 8 Powstańców Warszawy Ave., 35-959 Rzeszów, tel.: (17) 8651507, e-mail: m.wojcik@ @rz. edu.pl
} 


$$
\mathrm{M}_{\mathrm{n}}\left\{-\left(\mathrm{SiO}_{2}\right) \mathrm{q}-\mathrm{AlO}_{2-}\right\}_{\mathrm{n}}
$$

where: $\mathrm{M}$ - alkaline cation, $\mathrm{n}$ - polycondensation degree, $\mathrm{q}-\mathrm{Si} / \mathrm{Al}$ ratio.

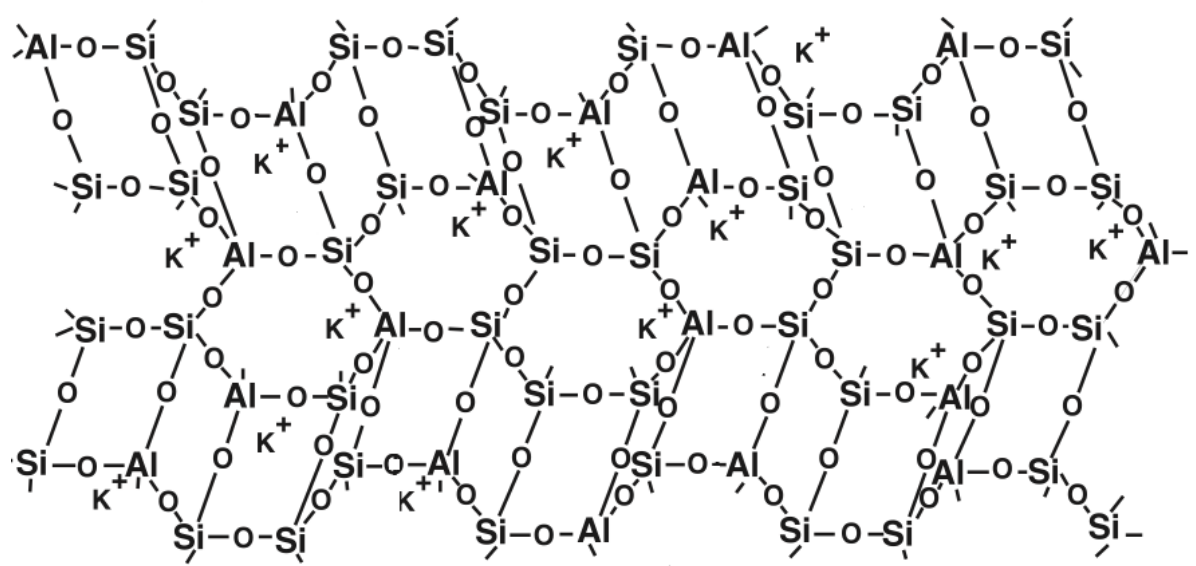

Fig. 1. The structure of aluminosilicate geopolymers [6]

The production of geopolymers works by shredding and drying of a puzzolanic material. After that, material is mixed with the aqueous solution of silicate and strong alkaline (Fig. 2). The main mechanism of geopolymerization consists of $[2,7]$ :

- the digestion of aluminosilicate oxides in aqueous solution of strong alkaline, e.g. $\mathrm{NaOH}$ or $\mathrm{KOH}$,

- the formation of gel which is a polycondensation product of silicate solution, silica and aluminium,

- the hardening of obtained gel.

Depending on the kind of material and activator used in the production, the properties of geopolymers are different. Another factor influencing the properties of material is the process conditions. Generally, geopolymers are characterized by [8]:

- the high resistance to compressing and bending,

- acid and alkaline resistance,

- the high heat resistance,

- the low porosity,

- the frost resistance,

- the relatively easy processing.

The aforementioned properties enable the application of geopolymers in many sectors of economy, especially in the construction sector. Geopolymers are commonly used in the production of face panels, bricks, tiles and other decoration elements. The unique properties also enable their usage as the protective coatings 
of steel, concrete and ceramics [9]. The usefulness of geopolymers in the construction sector is also caused by the lack of corrosion of steel reinforcement in this material and the high adhesion to steel. Additionally, geopolymers are characterized by the relatively low shrinkage during the curing which ensures the dimensional stability $[10,11]$. For this reason, geopolymers might be treated as an alternative solution to Portland cement.

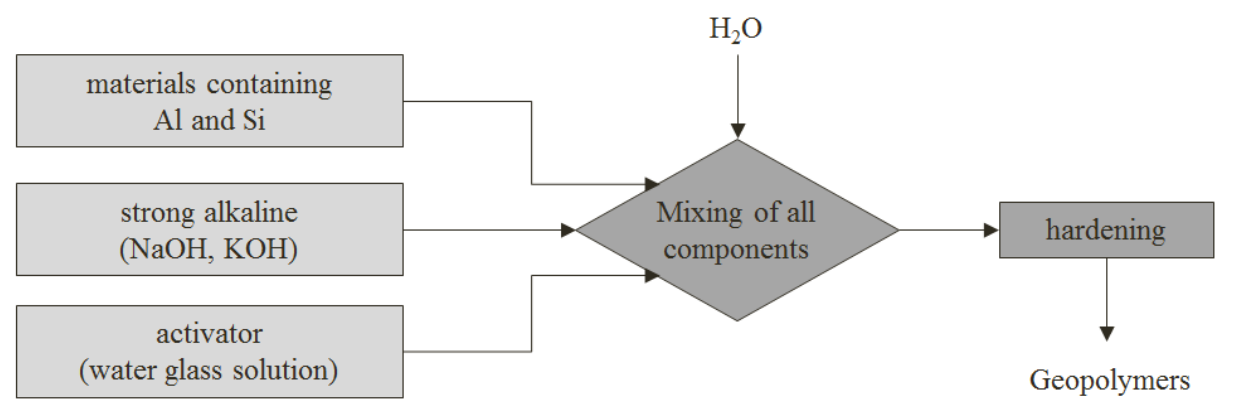

Fig. 2. The simplified diagram of the production of geopolymers

Recently, there has been increased interest in using of geopolymers in the environmental engineering. The aforementioned material is used in waste management more and more often in the production of tanks dedicated storage radioactive waste. Geopolymers are also applied as a coverage of the surface of landfill wastes [12].

The increasing application of geopolymers requires new materials which could be useful in their production. This paper presents the alternative materials used in the synthesis of geopolymers. In this article, the proposition of the application of asbestos waste and coal fly ashes in the production of geopolymers is also shown.

\section{Waste materials used in the production of geopolymers}

The wide range of the application of geopolymers requires searching for new materials which might be used in their synthesis. In literature, there are some works concerning the use of different substances in the production of geopolymers. Pacheco-Torgal et al. [13] used waste from the tungsten mine in the synthesis of geopolymers. Other studies indicated the usefulness of volcanic tuff, rice husk ash, cinder, sludge from water treatment, soft clay and marginal lateritic soil in the geopolymerization process [2, 5, 14-18]. Such obtained geopolymers are characterized by the high resistance to compression. The production of geopolymers with the use of fly ashes and shredded car tyres or coffee grounds was also tested $[19,20]$. 
But the most of papers are related with the application of fly ashes. The usefulness of ashes in geopolymerization is associated with the content of reactive aluminosilicate. Research carried out by Mikuła and Łach [2] showed that geopolymers containing fly ashes are characterized by the high resistance to heat.

Due to the content of reactive silica and aluminium and the small amount of calcium, asbestos might be used in the production of geopolymers. Asbestos is a fibber material classified to hydrated aluminosilicate. Depending on the chemical formula, asbestos minerals are divided into two classes: serpentine and amphiboles (Tab. 1) [21].

Table 1. Kinds of asbestos

\begin{tabular}{|c|c|c|}
\hline Kind of asbestos & Name of mineral & Chemical formula \\
\hline serpentine & chrysotile & $(\mathrm{Mg}, \mathrm{Fe})_{3} \mathrm{Si}_{2} \mathrm{O}_{5}(\mathrm{OH})_{4}$ \\
\hline \multirow{4}{*}{ amphiboles } & tremolite & $\mathrm{Ca}_{2}(\mathrm{Mg}, \mathrm{Fe})_{5} \mathrm{Si}_{8} \mathrm{O}_{22}(\mathrm{OH})_{2}$ \\
\cline { 2 - 3 } & actinolite & $\mathrm{Ca} 2(\mathrm{Mg}, \mathrm{Fe})_{5} \mathrm{Si}_{8} \mathrm{O}_{22}(\mathrm{OH})_{2}$ \\
\cline { 2 - 3 } & cummingtonite & $\left(\mathrm{Mg}, \mathrm{Fe}^{2+}\right)_{7} \mathrm{Si}_{8} \mathrm{O}_{22}(\mathrm{OH})_{2}$ \\
\cline { 2 - 3 } & grunerite & $\left(\mathrm{Mg}, \mathrm{Fe}^{2+}\right)_{7} \mathrm{Si}_{8} \mathrm{O}_{22}(\mathrm{OH})_{2}$ \\
\cline { 2 - 3 } & riebeckite & $\mathrm{Na}_{2}\left(\mathrm{Mg}, \mathrm{Fe}^{2+}\right)_{3} \mathrm{Fe}^{3+}{ }_{2} \mathrm{Si}_{8} \mathrm{O}_{22}(\mathrm{OH})_{2}$ \\
\cline { 2 - 3 } & anthophyllite & $\left(\mathrm{Mg}, \mathrm{Fe}^{2+}\right)_{7} \mathrm{Si}_{8} \mathrm{O}_{22}(\mathrm{OH})_{2}$ \\
\hline
\end{tabular}

The specific physical and chemical properties have enabled the application of asbestos in many sectors of economy. The culmination of its worldwide production is dated 70' and 80's [22]. Although, the production of asbestos in Europe is forbidden, a lot of waste containing this mineral could be in the environment. The resistance to different conditions caused that asbestos is non-degradable and might remain in the environment for a long time.

In order to reduce the harmful impact of asbestos waste on the environment and the human health, new recycling methods are required. The promising solution might be the application of properly prepared asbestos dust in the production of geopolymers.

\section{Utilization of asbestos waste in the production of geopolymers}

The proper utilization of asbestos waste is necessary from the economic and environmental point of view. Although there is a ban of the usage of asbestos in many countries, the worldwide production is estimated on 2 thousand tons [23]. Even though there are developed new recycling methods, the utilization of asbestos is still insufficient.

Asbestos waste might be used in the production of geopolymer concrete which could be applied in the construction sector. But before the application of asbestos in the geopolymerization, waste has to be properly prepared (Fig. 3). Firstly, asbestos should be shredded and grounded by means, for example ball 
mills. Due to the harmful influence of asbestos dust on the human health, the whole process should be undergone in sealed conditions. Afterwards, such obtained material should be thermally converted and grounded again. After preparation, obtained asbestos ash is stored in a silo.

The application of coal combustion by-products also demands previous preparation consisting of shredding and grinding (Fig. 4). The aforementioned processes might increase the whole efficiency of the production of geopolymers. Afterwards, the grounded ash is also stored in a container.

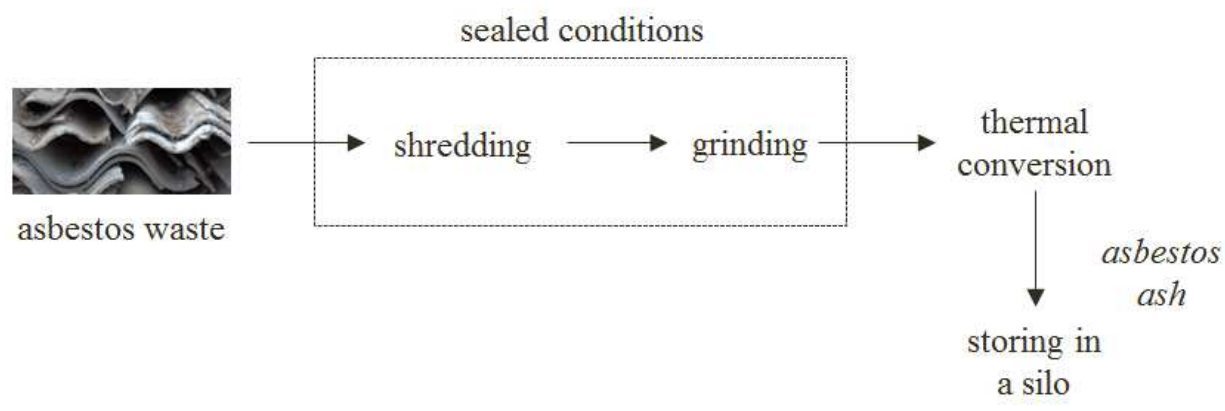

Fig. 3. Initial preparation of asbestos waste

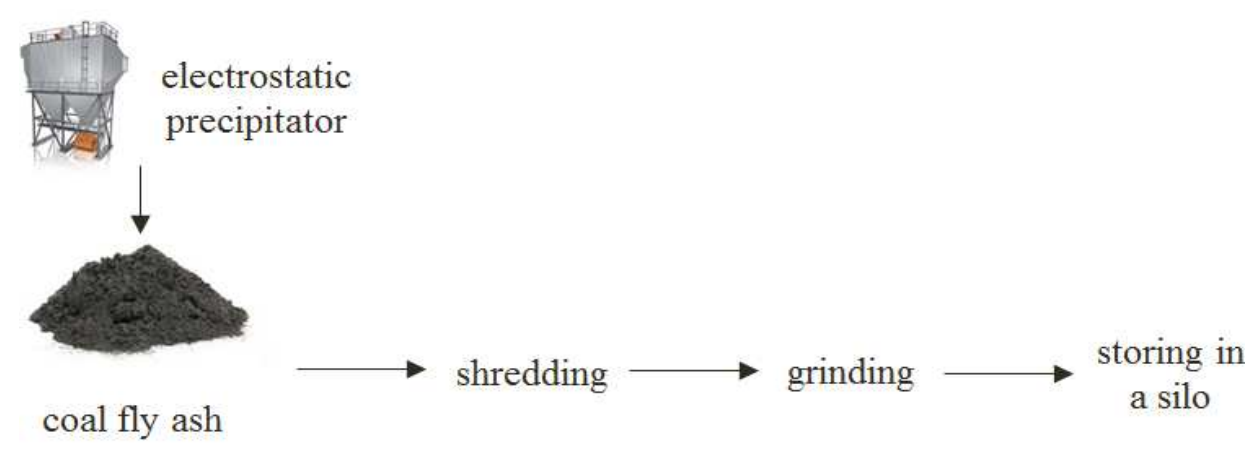

Fig. 4. Initial preparation of coal fly ashes

The proposition of asbestos recycling in the production of geopolymers is shown in Fig. 5. Firstly, properly prepared asbestos and fly ashes are transported to the mixing chamber with the use of screw feeder. The aforementioned ingredients are mixed together in order to obtain the mixture of loose materials. The mixing process is conducted in the dry conditions.

In the production of geopolymers, the alkaline solution of sodium hydroxide $(\mathrm{NaOH})$ might be applied. The $\mathrm{NaOH}$ in the form of flakes is transported to the mixing chamber by means of a screw feeder. Afterwards, sodium hydroxide is 
mixed with the aqueous solution of sodium silicate and tap water. The mass ratio of sodium silicate to sodium hydroxide should be in the range of 2.0:1.0-2.5:1.0. Such obtained solution is mixed with the previous prepared mixture of asbestos dust and coal fly ashes. The required mixing time of both ingredients should be approximately 20 minutes. At this stage, the homogenous and density plastic mass might be obtained. Depending on the application, the obtained product is properly formed and fired.

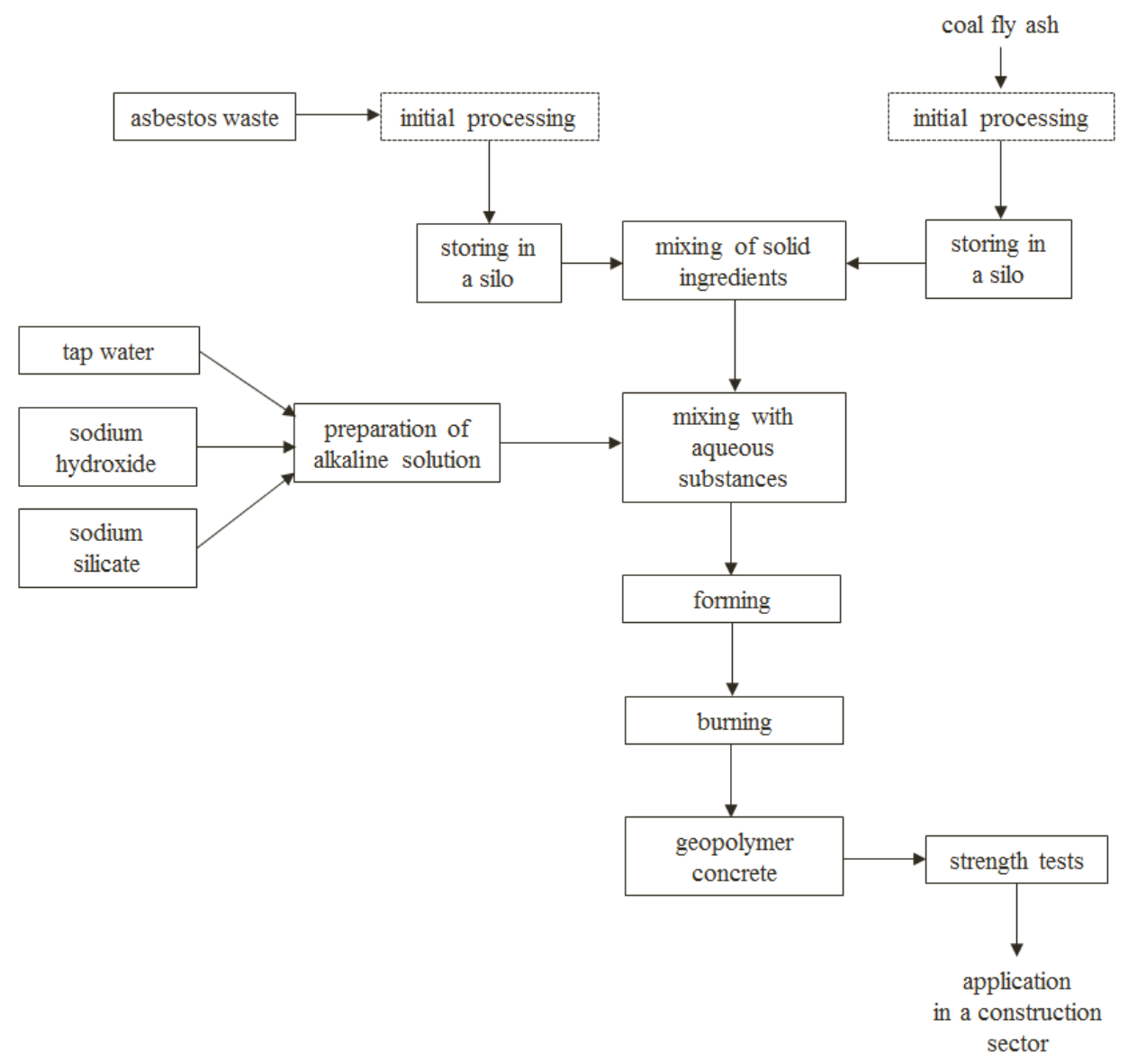

Fig. 5. Scheme of the use of asbestos and coal fly ashes in the production of geopolymers

\section{Summary}

The alternative solution for the utilization of asbestos could be its application in different sectors of economy. Due to the specific physical properties and chemical composition, asbestos waste might be applied in the production of geopolymer concrete. Geopolymers used in the construction industry are characterized by 
the lack of the corrosion of reinforcement and the high adhesion degree to steel. Additionally, the geopolymer concrete has much better strength characteristics than portland concrete.

Recently, there has been increased interest in the application of different fraction of waste in the production of geopolymers. Fly and bottom ashes, volcanic tuff or tungsten mine might be successfully used in the geopolymerization process. Referring to research carried out by different authors, the application of asbestos waste and coal fly ashes in the production of geopolymers was proposed. The aforementioned solution enables to utilize two problematic waste in line with legal requirements. The previous processing of asbestos waste reduced its harmful impact on the human health and on the environment. Additionally, the synthesis of geopolymers with the use of waste demands twice less of energy and emits eight two times less carbon dioxide in comparison to traditional ingredients [2]. By means of the advantageous environmental characteristic, geopolymer concrete is often called as ,green concrete".

The proposition is a new solution in both waste management and materials science. This method is innovative and has never been applied before. However, the further detailed research is necessary in order to examine the mechanism of process and the influence of asbestos on the characteristics of geopolymers.

\section{References}

[1] Fan F., Liu Z., Guoji X., Xu G., Peng H., Cai C.S.: Mechanical and thermal properties of fly ash based geopolymers, Constr. Building Mater., 160 (2018) 66-81.

[2] Mikuła J., Łach M.: Wytwarzanie i właściwości geopolimerów na bazie tufu wulkanicznego, Inżynieria Materiałowa, 3 (2014) 270-276.

[3] Khale D., Chaudhary R.: Mechanism of geopolymerization and factors influencing its development: a review, J. Mater. Sci., 42 (2007) 729-746.

[4] Liu Z., Cai C.S., Liu F., Fan F.: Feasibility study of loess stabilization with fly ash-based geopolymer, J. Mater. Civil Eng., 28 (2016) 35-41.

[5] Ryu G.S., Lee Y.B., Koh K.T., Chung Y.S.: The mechanical properties of fly ash-based geopolymer concrete with alkaline activators, Constr. Building Mater., 47 (2013) 409-418.

[6] Damilola O.M.: Syntheses, characterization and binding strength of geopolymers: A review, Int. J. Mat. Sci. Applications, 2 (2013) 185-193.

[7] Xu H., Van Demeter J.: The geopolimerization of aluminosilicate materials, J. Mineral Processing, 59 (2000) 247-266.

[8] Brinson H.F., Brinson C.: Polymer Engineering Science and Viscoelasticity, Springer 2008.

[9] Yong S.L., Feng D.W., Lukey G.C., Van Demeter J.: Chemical characterisation of the steel-geopolymeric gel interface, Colloids and Surfaces A: Physicochemical Eng. Aspects, 302 (2007) 411-423.

[10] Król M., Błaszczyński T.Z.: Ekobetony geopolimerowe, Materiały Budowlane, 11 (2013) 23-26. 
[11] Mikuła J.: Nieorganiczne polimery glinokrzemianowe (geopolimery) - otrzymywanie, właściwości, przykłady zastosowania, http://docplayer.pl /31939858-Nieorganiczne-polimery-glinokrzemianowe-geopolimery-otrzymywa nie-wlasciwosci-przyklady-zastosowania.html (access: 26.01.2018).

[12] Nikolić I., Tadić M., Durović D., Zejak R., Mugoša B.: Stabilization/solidification of spent grint in fly ash based geopolymers, Environ. Protection Eng., 41 (2015) 5-14.

[13] Pacheco-Torgal F., Castro-Gomez J.P., Jalali S.: Investigations of tungsten mine waste geopolymeric binder: Strengh and microstructure, Constr. Building Mater., 22 (2008) 2212-2219.

[14] Phetchuay C., Horpibulsuk S., Arulrajah A., Suksiripattanapong C., Udomchai A.: Strength development in soft marine clay stabilized by fly ash and calcium carbide residue based geopolymer, Applied Clay Sci., 127-128 (2016) 134-142.

[15] Phummiphan I., Horpibulsuk S., Sukmak P., Chinkulkijniwat A., Arulrajah A., Shen S.L.: Stabilisation of marginal lateritic soil using high calcium fly ash-based geopolymer, Road Mater. Pavement Design, 17 (2016) 877-891.

[16] Sturm P., Gluth G.J.G., Brouwers H.J.H., Kühne H.C.: Synthesizing one-part geopolymers from rice husk ash, Constr. Building Mater., 124 (2016) 961-966.

[17] Suksiripattanapong C., Horpibulsuk S., Chanprasert P., Sukmak P., Arulrajah A.: Compressive strength development in geopolymer masonsy units manufactured from water treatment sludge, Constr. Building Mater., 82 (2015) 20-30.

[18] Ul Haq E., Padmanabhan S.K., Licculli A.: Synthesis and characteristics of fly ash and bottom ash based geopolymers - A comparative study, Ceramics Int., 40 (2014) 2965-2971.

[19] Kua T-A., Arulrajah A., Mohammadinia A., Horpibulsuk S., Mirzababaei M.: Stiffness and deformation properties of spent coffee grounds based geopolymers, Constr. Building Mater., 138 (2017) 79-87.

[20] Mucsi G., Szenczi Ă., Nagy S.: Fiber reinforced geopolymer from synergic utilization of fly ash and waste tire, J. Cleaner Production, https://www.sciencedirect.com/science/article/pii/S0959652618300246 (access: 26.01.2018).

[21] Abú-Shams K., Pascal I.: Asbestos: characteristics, properties, pathogenesis and sources of exposure, Anales Del Sistema Sanitario De Navarra, 28 (2005) 7-11.

[22] Bajorek R., Parosa R.: Technologia mikrofalowa - nowatorski sposób utylizacji azbestu, Dom Wydawniczy Medium, Warszawa 2009.

[23] Wójcik M.: Azbest w odpadach motoryzacyjnych. Współczesne metody recyklingu odpadów azbestowych z sektora motoryzacyjnego, Autobusy (2018) (to be published). 


\section{ODPADY W PROCESIE GEOPOLIMERYZACJI. PROPOZYCJA ZASTOSOWANIA PYŁU AZBESTOWEGO I POPIOŁU LOTNEGO W PRODUKCJI BETONU GEOPOLIMEROWEGO}

\section{Streszczenie}

Specyficzne właściwości fizykochemiczne oraz mechaniczne skutkują systematycznym wzrostem światowej produkcji geopolimerów. Wytrzymałość mechaniczna oraz niska podatność na działanie wysokiej temperatury determinują możliwość zastosowania geopolimerów w wielu dziedzinach gospodarki, w szczególności w sektorze budowalnym. Dodatkowo, niska emisja dwutlenku węgla na etapie produkcji powoduje, że geopolimery są traktowane jako materiał ekologiczny. Szerokie spektrum zastosowania geopolimerów wymaga poszukiwania nowych materiałów przydatnych do ich produkcji. Z ekologicznego punktu widzenia najkorzystniejszym rozwiązaniem jest zastosowanie w procesie syntezy geopolimerów produktów odpadowych. Ze względu na obecność w swoim składzie krzemu i glinu, pył azebestowy może wykazywać przydatność do wytwarzania geopolimerów. Artykuł przedstawia propozycję recyklingu odpadów azbestowych i popiołu lotnego ze spalania węgla w produkcji betonu geopolimerowego. Końcowy produkt zaproponowanej metody może być zastosowany w budownictwie, bez negatywnego wpływu na środowisko. Przedstawiona propozycja umożliwia utylizację szkodliwego materiału, jakim jest pył azbestowy, zgodnie $\mathrm{z}$ hierarchią postępowania z odpadami oraz zasadą zrównoważonego rozwoju.

Słowa kluczowe: odpady azbestowe, popiół lotny, geopolimery, recykling, budownictwo, inżynieria lądowa

DOI: $10.7862 / \mathrm{rm} .2018 .21$

Przestano do redakcji: 23.04.2018

Przyjęto do druku: 20.05.2018 
